\title{
PENYEDIAAN MCK DARURAT DI KAMP PENGUNGSI BERBASIS MASYARAKAT
}

\author{
Lita Asyirati Latif 1, Endah Harisun² \\ ${ }^{1}$ Program Studi Teknik Mesin Fakultas Teknik Universitas Khairun, Ternate \\ ${ }^{2}$ Program Studi Arsitektur Fakultas Teknik Universitas Khairun, Ternate \\ email lithalatif@yahoo.com, endah.harisun@unkhair.ac.id
}

\begin{abstract}
ABSTRAK
Bencana alam gempa bumi dengan 7,2 pada skala Richter yang melanda Kabupaten Halmahera Selatan sangat berdampak besar pada rusaknya rumah penduduk maupun fasilitas umum dihampir seluruh desa yang terkena dampak gempa bumi. Desa Tawa yang merupakan salah satu desa yang terkena dampak sangat parah akibat bencana gempa tersebut. Melalui gerakan Fakultas Teknik peduli korban bencana Halmahera Selatan dan kegiatan program Pengabdian Kepada Masyarakat (PKM) Fakultas Teknik tahun 2019, Fakultas Teknik mencoba membantu masyarakat Halmahera Selatan khususnya masyarakat desa Tawa dalam membangun sarana dan prasaran desa tersebut. Salah satunya adalah penyediaan MCK darurat di kamp pengungsi yang berbasis masyarakat. Berdasarkan pantauan langsung di lapangan, kebutuhan akan sarana Mandi, Cuci, Kakus (MCK) darurat sangat diperlukan masyarakat desa Tawa. Pendekatan yang dilakukakan dalam kegiatan pengabdian ini adalah dengan cara memberikan bantuan material berupa seng, kloset, perlengkapan pertukangan serta melakukan pendampingan dalam pembuatan MCK darurat. Dengan ketersediaan MCK darurat dapat membantu masyarakat pengungsi dalam beraktivitas dan terhindar dari berbaga penyakit yang diakibatkan oleh sanitasi yang buruk seperti penyakit diare, kolera dan demam.
\end{abstract}

Kata Kunci : Desa Tawa, Fakultas Teknik, Halmahera Selatan, MCK darurat

\begin{abstract}
The 7.2 magnitude earthquake that struck South Halmahera Regency had a major impact on the damage to residents' homes and public facilities in almost all the villages affected by the earthquake. Tawa Village is one of the villages affected by the earthquake. Through the movement of the Faculty of Engineering concerned about the victims of the Halmahera Selatan disaster and the activities of the Faculty of Engineering (PKM) in 2019, the Faculty of Engineering is trying to help the people of South Halmahera especially the Tawa village community in building village facilities and infrastructure. One of them is the provision of emergency toilets in communitybased refugee camps. Based on direct observations in the field, the need for emergency bathing, washing, toilet (MCK) facilities is urgently needed by the Tawa village community. The approach taken in this service activity is to provide material assistance in the form of zinc, toilets, carpentry equipment and provide assistance in making emergency toilet facilities. With the availability of emergency KMC, it can help refugees in their activities and avoid various diseases caused by poor sanitation such as diarrhea, cholera and fever.
\end{abstract}

Keywords : Emergency MCK, Faculty of Engineering, South Halmahera, Tawa Village, 


\section{PENDAHULUAN}

\section{Latar Belakang}

Bencana alam yang terjadi di seluruh dunia ini tidak dapat kita elakan. Bencana-bencana tersebut seperti bencana kebakaran, tanah longsor, puting beliung, tsunami maupun gempa bumi. Letak Indonesia secara geografis berada pada posisi antara benua Asia dan benua Australia, serta antara samudra pasifik dan samudra Hindia (Indonesia). Posisi ini sangat berpengaruh pada keadaan iklim, cuaca dan musim yang berlaku di wilayah Indonesia (Kesos, 2013).

Seperti kita ketahui baru-baru ini terjadi gempa bumi dengan 7,2 pada skala Richter yang melanda kabupaten Halmahera Selatan, dan berdampak pada rusaknya rumah penduduk maupun fasilitas umum di hampir seluruh desa yang terkena dampak gempa bumi.

Korban dari bencana alam akan menghadapi kondisi dan situasi yang cukup kompleks. Kondisi ini dialami baik secara sosial, psikis maupun fisik. Permasalahan yang paling mendasar adalah persoalan fisik, seperti pemenuhan tempat tinggal, kebutuhan makan dan minum, kesehatan dan pendidikan. Hal ini disebabkan karena kurang tersedianya fasilitas umum, fasilitas sosial dan sanitasi. Lingkungan yang buruk dapat mimbulkan ketidaknyamanan dan dapat menjadi sumber penyakit (Rusmiyati \& Hikmawati, 2012).

Fakultas Teknik Universitas Khairun yang merupakan Fakultas yang langsung berhubungan dengan kebutuhan sarana dan prasarana tersebut melalui Gerakan Peduli Korban Bencana Halmahera Selatan, mencoba membantu masyarakat Halmahera Selatan khususnya masyarakat desa Tawa dalam membangun sarana dan prasaran desa tersebut. Salah satunya adalah penyediaan MCK darurat di kamp pengungsian yang berbasis masyarakat.

\section{METODE}

Kegiatan program Pengabdian Kepada Masyarakat (PKM) Fakultas Teknik tahun 2019, difokuskan pada membantu masyarakat korban bencana gempa bumi 7,2 Skala Richter yang terjadi di Kabupaten Halmahera Selatan. Kegiatan PKM tersebut berupa :

- Memberikan bantuan sosial (bantuan materil seperti bahan bangunan, kebutuhan pokok sehari-hari beras, gula dan kebutuhan lainnya).

- Kegiatan Sosialisasi rumah tahan gempa, pemanfaatan PLTS, Teknik Pertukangan dan lainnya.

- Pendampingan Kepada Masyarakat seperti pembangunan sarana dan prasarana desa Tawa 
Berdasarkan pantauan langsung di lapangan, kebutuhan akan sarana Mandi, Cuci, Kakus (MCK) darurat sangat diperlukan masyarakat desa Tawa. Sehingga salah satu bagian dari kegiatan pendampingan kepada masyarakat adalah pembuatan MCK darurat bagi masyarakat desa Tawa.

Pendekatan yang dilakukakan adalah dengan cara memberikan bantuan material berupa seng, kloset, perlengkapan pertukangan serta melakukan pendampingan dalam pembuatan MCK darurat.

\section{PEMBAHASAN}

Langkah awal adalah melakukan sosialisasi dengan pihak aparatur desa Tawa tentang penentuan lokasi dari MCK darurat serta tahapan pembangunannya. Hal ini harus cepat dilakukan mengingat masih banyak masyarakat yang masih tinggal di kamp-kamp pengungsian.

Kondisi kamp pengungsian yang sempit serta fasiitas umum yang terbatas, membuat masyarakat pengungsi akan sangat tidak betah untuk tinggal berlama-lama di kamp pengungsian (Nadeak, 2016).

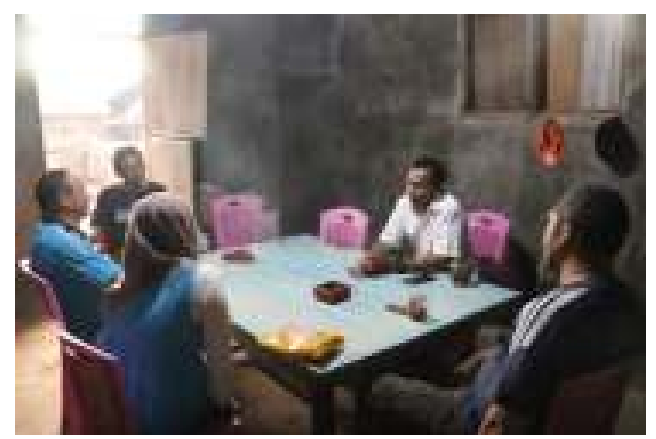

Gambar 1. Pertemuan dengan kepala desa Tawa

Menurut buku panduan sederhana berjudul "Mandi Cuci Kakus Berbahan Daur Ulang”, sarana MCK adalah sarana yang digunakan untuk kegiatan mandi, cuci dan buang air. MCK komunal harus ditempatkan di lokasi permukiman pengungsi pemukiman yang berpenduduk dengan kepadatan tinggi (> 200 orang/Ha). Sarana MCK harus memiliki fasilitas penyediaan air bersih yang memadai. Desain MCK sangat berhubungan dengan kebiasaan dari masyarakat atau budaya masyarakat setempat. Hal ini perlu dimusyawarahkan dengan masyarakat setempat melalui aparatur desa (Hadimoeljono, M Basuki, 2016).

MCK komunal juga menjadi syarat dari MCK darurat yang harus memenuhi ketentuan-ketentuan teknis yang disyaratkan. Berikut ketentuan umum dari penentuan lokasi MCK komunal adalah sebagai berikut: 
1. Perlu diperhatikan kebiasaan atau budaya masyarakat berhubungan dengan tata letak, pemisahan antara ruang laki laki dan ruang untuk wanita dan orang jompo atau cacat.

2. Lokasi MCK komunal dapat diterima oleh masyarakat (pengungsi) dan memenuhi persyaratan teknis yang disyaratkan.

3. Adanya keinginan dari masyarakat untuk mendirikan MCK.

4. Sudah tersedia saluran air bersih.

5. Lokasi MCK harus bebas dari bahaya banjir.

6. Pengoperasian dan pemeliharaan KMC dilakukan oleh kelompok masyarakat dan aparatur desa atau unit pelayanan teknis pemerintah setempat.

7. Ketersediaan badan air dalam mengalirkan efluen yang telah memenuhi standar mutu air limbah domestik dari IPAL.

8. Bangunan MCK baik komual maupun darurat perlu dilengkapi dengan adanya sistem plambing atau perpipaan air bersih, perpipaan air limbah, drainase dan ventilasi (Hadimoeljono, M Basuki, 2016).

Berdasarkan ketentuan diatas, lokasi MCK darurat terletak di daerah pegunungan yang juga merupakan lokasi dari kamp pengungsi masyarakat desa Tawa. Hal ini dikarenakan pasca gempa bumi, masyarakat desa Tawa mengungsi ke daerah ketinggian untuk menghindari bencana susulan yaitu Tsunami.
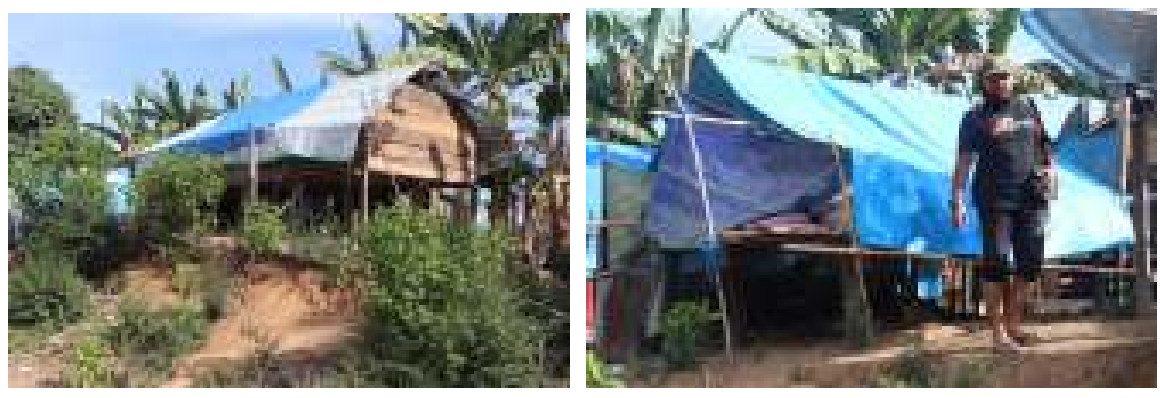

Gambar 2. Lokasi kamp pengungsian masyarakat desa Tawa

Setelah menyepakati lokasi MCK darurat dengan masyarakat, maka dibangunlah dua unit MCK darurat dengan ketentuan atau persyaratan teknis yang disyaratkan.

Pendekatan perencanaan bangunan ini diusahakan untuk meminimalisasi berbagai pengaruh yang berbahaya pada kesehatan masyarakat dan kesehatan lingkungan (Harisun, Endah. Awedy, 2017). 

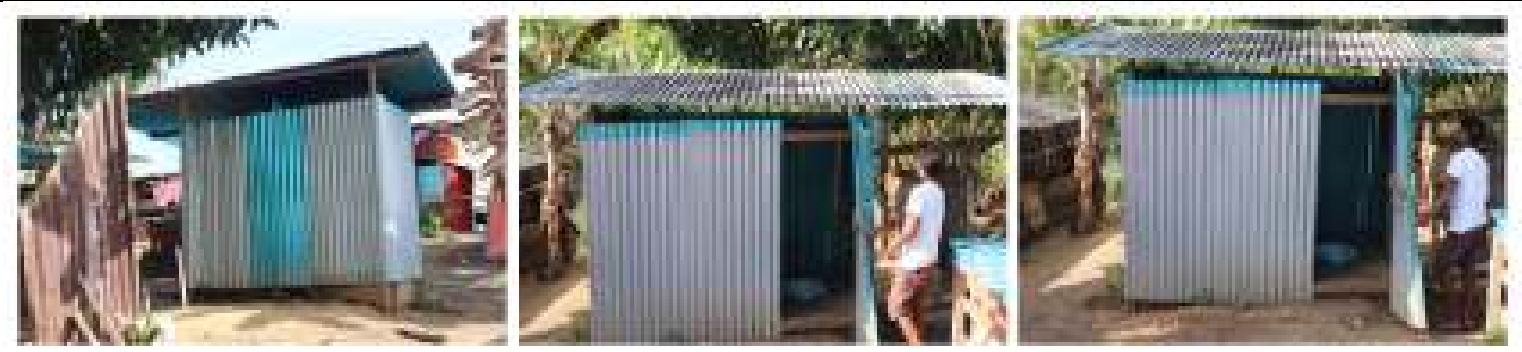

Gambar 3. Pembangunan MCK Darurat

Pembangunan MCK darurat dilakukan oleh swadaya masyarakat dengan menggunakan material dari bantuan Fakultas Teknik dengan pendampingan yang dilakukan oleh tim dari Fakultas Teknik.
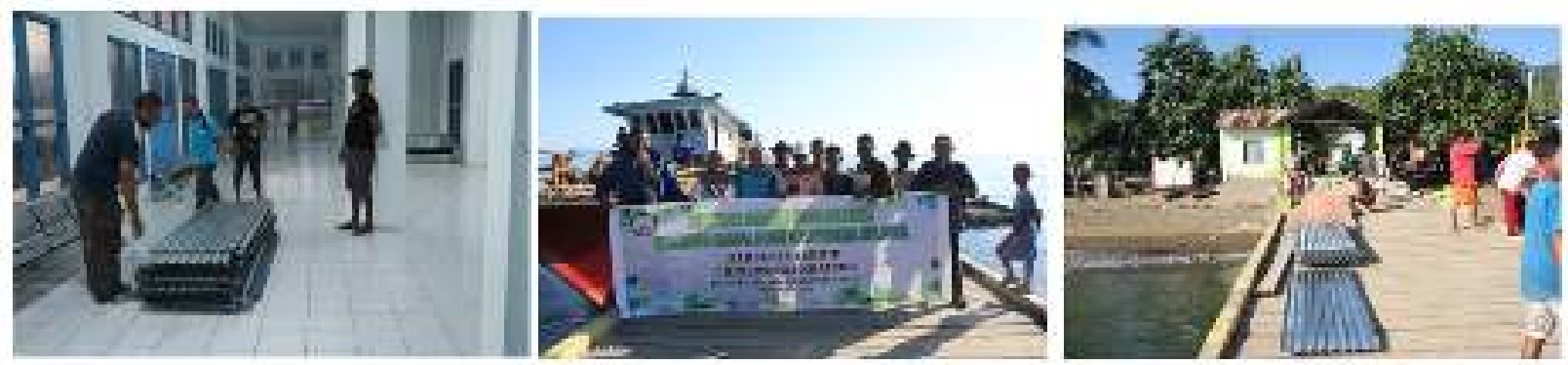

Gambar 4. Bantuan Material untuk pembuatan MCK Darurat

Penggunaan bahan bangunan yang terkandung didalamnya harus mengurangi polusi yang disebabkan oleh aktivitas manusia dan aktivitas yang bisa merusak lingkungan (Harisun, 2018).

\section{SIMPULAN}

Kegiatan Fakultas Teknik Peduli Gempa Halmahera Selatan yang digagas oleh dekan Fakultas Teknik berupa bantuan tenaga teknis, bahan baku, material infrastruktur, sosialisasi dan pendampingan kepada masyarakat dapat meringankan beban dari masyarakat yang terkena dampak gempa bumi serta dapat membantu pemerintah dalam kegiatan tanggap darurat bencana.

Ketersediaan MCK darurat dapat membantu masyarakat pengungsi dalam beraktivitas dan terhindar dari berbagai penyakit yang diakibatkan oleh sanitasi yang buruk seperti penyakit diare, kolera dan demam. 


\section{UCAPAN TERIMAKASIH}

Ucapan terimakasih ditujukan kepada Lembaga Penelitian dan Pengabdian Masyarakat (LPPM) Universitas Khairun yang telah membantu Fakultas Teknik Universitas Khairun dalam penyelenggaraan program Pengabdian Kepada Masyarakat (PKM) Fakultas Teknik tahun 2019.

\section{DAFTAR PUSTAKA}

Hadimoeljono, M Basuki, D. I. Ms. (2016). Mandi Cuci Kakus Berbahan Daur Ulang. Buku Panduan, $1-61$.

Harisun, Endah. Awedy, U. R. (2017). Perancangan Bangunan Mixed Use Building dengan Pendekatan Green Building di Ternate. Archipelascape, 3, 23-28.

Harisun, E. (2018). Folajikusesurabi Traditional House. 1(Icst), 364-371.

Kesos, B. (2013). Peran Nurani Astra dalam Penanganan Korban Bencana Alam The Role of. (1), 197206.

Nadeak, E. (2016). Strategi Kelangsungan Hidup Rumah Tangga Korban Erupsi Gunung Sinabung Di Kabupaten Karo Provinsi Sumatera Utara. Jurnal Ilmu Administrasi Publik, 4(2), 162-174.

Rusmiyati, C., \& Hikmawati, E. (2012). Penanganan Dampak Sosial Psikologis Korban Bencana Merapi (Sosial Impact of Psychological Treatment Merapi Disaster Victims). 17(02), 97-110. 